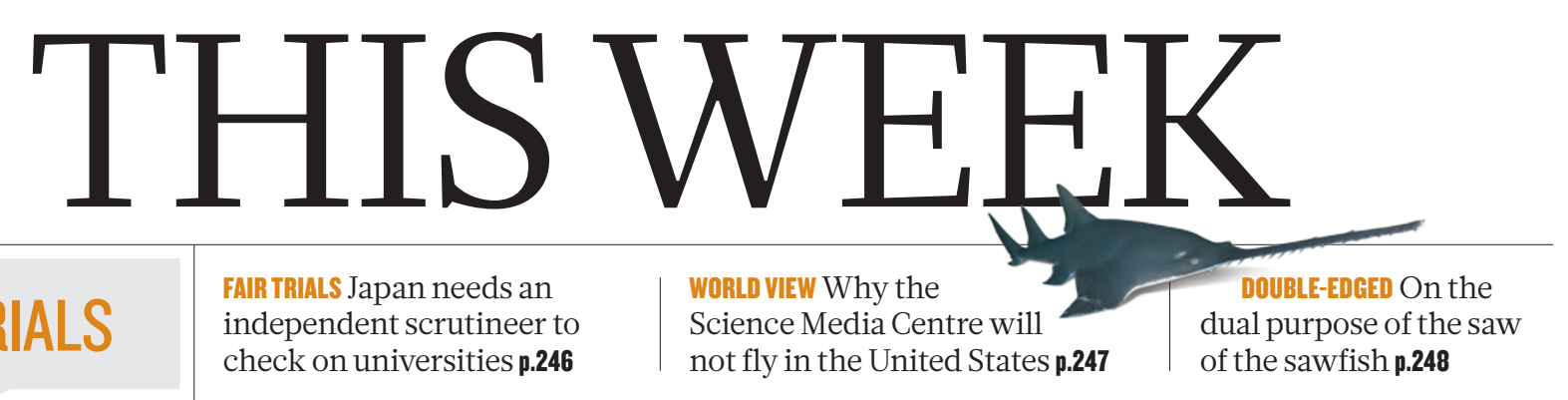

\title{
A Russian renaissance?
}

\section{Vladimir Putin's promise to increase research spending is welcome - but his country's scientific system needs a complete overhaul.}

$\mathrm{T}$ he plight of Russian science was far from the minds of most of the protesters filling Moscow's streets after the disputed parliamentary poll in December and the equally contested presidential elections on $4 \mathrm{March}$. The protests, the largest in the country for 20 years, reflect the alienation of Russia's intelligentsia and rising urban middle-class from its inbred political leadership, and the autocratic tendencies scarcely veiled behind its assertions of democracy. Yet the crowds' grievances do mirror some of the problems that are keeping Russian science down.

There is no doubt that the scientific system seriously lacks money. Vladimir Putin's pre-election promise to pump funding into basic science and innovation (see page 253) as part of his plan to modernize and diversify Russia's stagnating economy, which is heavily dependent on energy exports, is welcome. His spending promises - and his opponents' general lack of interest in science - may explain why many Russian academics and working scientists voted to return Putin to the presidency.

But Russian science is undergoing a crisis that runs deeper than money: the country's publication output has declined in the past decade despite a slight recovery of the still-meagre public science budgets. More than 20 years after the end of the Soviet Union, Russia's large research community is fundamentally divided over how it would like the domestic science funding system to operate.

Russian scientists of all ages - not just those who have come of age since the fall of the Soviet Union - are sincerely inclined towards liberal democracy and open intellectual discourse. They believe that scientific systems based on peer-reviewed grant applications, although fiercely competitive, are preferable to any form of prescribed knowledge production. But an influential class of old-school academicians and science administrators would rather return to communist secret practices than accept the norms and standards of what they see as Western science. Peer review? Project evaluation? Perish the thought.

It is mostly the latter group - together with Russia's omnipresent Federal Security Service, formerly run by Putin - that has created the stifling bureaucracy and perplexing jungle of regulations and restrictions that many aspiring Russian scientists, let alone their foreign collaborators, have learned to hate. The travel and security restrictions that some Russian physicists are currently protesting against are just the most recent example of the harassment to which the apparatchiks subject scientists (see Nature http://dx.doi.org/10.1038/nature.2012.9921; 2012). Worse, favouritism and corruption pervade science and higher education - there is bribery from the lowest levels, with students paying teachers in exchange for passing exams, to the highest.

If science is to have a constructive role in shaping Russia's future, Putin must tackle these problems as forcefully as possible. Economists say that a key test of his leadership will be how far he is prepared to go to reform the economy; his agenda should also include kick-starting overdue scientific reform. Rather than relying on the advice of an

exclusive inner circle of buddies and dignitaries, as he has in the past, Putin should set up a truly independent scientific advisory council, ideally involving foreign scientists, to guide him through the necessary changes. Russia's partnership with the Massachusetts Institute of Technology in Cambridge, which will help to set up a new research

"Putin should set up a truly independent science advisory council." scientific landscape of any foreign nation, but the blindness of parts of its scientific establishment to the necessity of change borders on negligence. It is time for that establishment to throw overboard the stubborn obscurantism that stands in the way of a renaissance of Russia’s proud scientific past.

\section{The shared burden}

\section{A proposed change to Germany's constitution is needed for the future health of the universities.}

$\mathrm{I}$ $t$ is hard to find anyone who can offer a sensible explanation for why the 16 German states signed up to a reform in 2006 that prevented the federal government from directly injecting cash into their universities. Federal funds had previously been used to share the considerable burden of financing infrastructure and large equipment in universities, for which the states have general responsibility. The reform made such sharing impossible. And that left universities, particularly those in poorer states, to deteriorate in quality.

Both federal and state governments now agree that the situation must be reversed - urgently, given the relative underfunding of German universities. A proposal on 4 March by education and research minister Annette Schavan aims to do just that.

But the required (two-word) change to the German constitution is opposed by some political parties and certain states. Opponents say that the reform should not be limited to universities, and should allow the federal government to co-finance schools too - a demand that Schavan cannot accept.

To understand the situation, one has to look back to Germany's 1949 post-war constitution, which was designed to ensure that a dictator could never again seize centralized power. This involved the creation of a highly federalized country with politically strong state governments. 